\title{
Utilization of Wastewater from Different Sources as Potential Electrical Energy Source
}

\author{
Melvin D. Hagonob', Leomarich F. Casinillo2* \\ ${ }^{1}$ Visayas State University, Baybay City, Philippines, \\ https://orcid.org/0000-0002-6925-1778 \\ 2 Visayas State University, Baybay City, Philippines, \\ https://orcid.org/0000-0003-3966-8836 \\ *Email Correspondence: leomarich_casinillo@yahoo.com
}

\section{Abstract}

This study is about the generated electricity from wastewater using carbon electrodes with the absence/presence of salt bridge through the biofilm anode of the microbial fuel cell (MFC) technology. The three wastewater samples used were from a pond, an abaca pulp mill, and rice fields. Results showed that one of the abaca pulp mill treatments, using carbon rod electrodes with salt bridge presence, reached the highest mean voltage and current to $578.7 \mathrm{mV}$ and $0.2022 \mathrm{mV}$, respectively. The study revealed that the number of sensible power generation days, from start to end of experimentation, has a significant difference between treatments. Throughout the 20-day fermentation process, a total count of $8.94 \times 10^{5}$ colony forming units (CFU) per $\mathrm{ml}$ was found and purified from the biofilm anodes from pond wastewater. Likewise, $9.14 \times 10^{5} \mathrm{CFU}$ per $\mathrm{ml}$ isolates from the abaca pulp mill, and $1.65 \times 10^{6}$ CFU per $\mathrm{ml}$ isolates from the rice field.

Keywords: wastewater, carbon electrodes, biofilm anode, microbial fuel cell, electrical energy

\subsection{Introduction}

Our society is constantly searching for sustainable, renewable, and alternative energy sources (Brockway et al., 2019; Li, 2013; Panwar et al., 2011). In most cases, people only think of solar cells or windmills for energy sources. However, microbial fuel cells (MFCs) may also be part of the picture. Seemingly, MFCs is a form of renewable energy which is considered to be a technology that generates electrical energy from what would otherwise be considered waste (Kim et al., 2007). According to Treesubsuntorn et al.
(2019), MFCs considers using bacteria to generate electricity for a new source of potential energy and innovations about microbial physiology in the electron transport. Perhaps, it also considers an advancement of fuel cell technologies.

It is worth noting that MFCs produce electricity from organic matter. Based on the previous work done by Min et al. (2005), MFC had been established to produce electrical energy directly from marine residues, anaerobically absorbed sludge, food wastewaters, domestic wastewater and the likes. Perhaps, the quantity of energy or power produced 
varies which depends on the category of reactor and the organic matter's precise source (Atanacio et al., 2010). Seemingly, MFCs has a lot of advantages such as high energy-conversion efficiency and mild reaction conditions, unlike conventional fuel cells. MFCs uses an amount energy more efficiently compared to a standard combustion engines which follows the Carnot Cycle. Hence, MFC is proficient of energy effectiveness for about 50\% and beyond. With the aid of the new MFCs, energy conversion to hydrogen is about eight (8) times as high as the conventional. Seemingly, a lot of the discoveries accomplished on MFCs are focused on increasing the system's power density concerning the peripheral anode surface area (Zielke, 2005). In contrast, few investigation has been done in the literature on determining the effects of voltage output compared to varying fuel cell components.

This study uses a single chamber-designed air cathode microbial fuel cell is used. A simpler MFC is made where the cathode chamber is omitted and placed directly into the proton exchange membrane or salt bridge (Ashoka et al., 2012). Wastewaters are abundant almost worldwide as the population growth increases exponentially, so with the pollution and waste in the environment. Producing energy from wastewater should be prioritized because of the continuous population growth and worldwide reduction of natural resources. Apparently, several researchers are involved in producing electrical energy and its management strategy (Kharbanda et al., 2019; J. Liu et al., 2019; Marzougui et al., 2019; Ryu \& Kim, 2019). In the Philippines, dumping of wastewater is quite a challenge. Perhaps, the governments in the different regions have to formulate policies and guidelines to ensure proper wastewater management (Jensen \& Wu, 2018). The data on the total volume of wastewater generated by municipal and industrial sectors in the Philippines is not readily available from the concerned agencies. Hence, the data was only an estimate produce from municipal, industrial sectors and major agricultural industries (Banaticla \& Rivera, 2011). The estimated data may be considered inadequate because other industries' produce wastewater are not readily available. The dominant wastewater treatments are primary and secondary treatments depending on the wastewater's physical and chemical constituents, and the standard quality of effluents before its discharge to the surface of the water or land. Atanacio et al. (2010) stated in his recent study, wastewater and other toxic liquid residues (e.g., cassava extract) are a prevailing problem in the Philippines. These are coming from processing plants and the waste extracted from different crops and residues. If not properly disposed these wastewaters will either eventually cause death, or may create other threats to human beings and other human organisms. That is why the government has to set many policies to address these problems.

In the Philippines, research and knowledge on MFCs regarding utilizing different wastewaters as electricity sources are new and underdeveloped. Furthermore, improving MFC technology in the Philippines needs deeper understandings and research, especially in different wastewaters and other crop residues. Besides, focusing on the limitations and microbiology processes of these systems is required. Thus, this research study aimed to provide information on optimizing electricity generation, specifically on different wastewater sources. In general, this study aimed to determine the potential of wastewater from different sources as a source of electrical energy using an improvised air-cathode MFC. Specifically, this study was performed to (1) develop a laboratory microbial 
fuel cell for the generation of electricity using three different sources: pond, abaca pulp mill, and rice field wastewater; (2) determine the amount of electrical energy (voltage and current) that can be generated from different wastewater sources using two types of carbon electrodes with the presence and absence of salt bridge; (3) isolate and characterize the microorganisms present in the wastewaters of different sources.

\subsection{Methodology}

\section{Procurement of Raw Material}

The wastewater for the anode chamber was collected from the different sources in Baybay City,
Leyte. The first source was obtained from the pond near the Visayas State University (VSU) Laboratory High School. The second source came from the abaca pulp mill located in Barangay Hilapnitan. Another source of wastewater was taken from the VSU rice field inside the campus. The carbon block was taken from the Philippine Root Crops Center in VSU. The carbon rod electrodes were obtained from the dry cell batteries. The plastic containers were obtained from Ormoc City, Leyte. Stranded wires, epoxies, magnetic wires, soldering leads, and soldering irons were purchased from Poping Electronics in Baybay City, Leyte. The process of the experiment is shown in Figure 1.

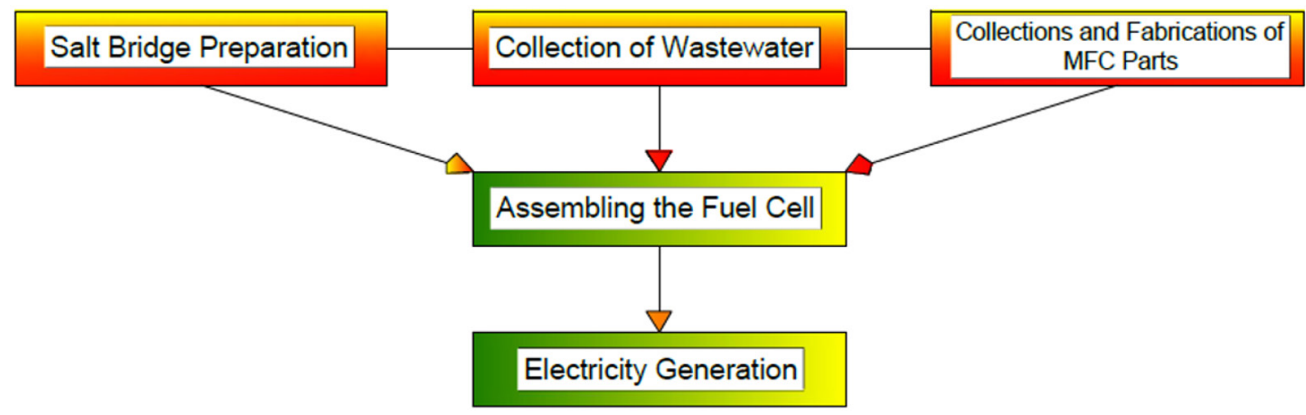

Figure 1. Schematic Diagram of the Whole Process of the Experiment

\section{Development of the Improvised MFC}

The improvised MFC was used to convert the wastewater from different sources into electrical energy through the catalytic reaction of the wastewater's microorganisms. In this study, two designs were used namely: the air-cathode MFC with the absence and presence of salt bridge. The two designs were only composed of a single chamber for anode and cathode. The 1.5 liter-sized soft drink were used as containers. The schematic diagrams of the two designs are shown in Figure $2 a$ and Figure $2 b$.
The Anode and Cathode Chamber. Each set of MFC was composed of a single chamber. The chamber for anode and cathode using 1.5 liter-sized plastic containers associated with lid compose additional materials such as sealing material, stranded wire, magnetic wire, soldering lead and carbon electrodes. The carbon electrodes served as the cathode or the positive charge and the anode or the negative charge. The same material was used both for the anode and cathode. The stranded wires and electrodes were partially connected using magnetic wires. It was done using 
soldering lead and soldering iron. Each of the carbon electrodes was permanently connected with the wire. The connections were sealed with epoxy (sealing material) to prevent the wire's from contacting to the wastewater.

For the anode, the electrode with wire was attached at the bottom part of the container. For the cathode electrodes with a salt bridge's absence, a small portion of the electrode was exposed inside the container. The other portion was exposed to the air. While with the presence of a salt bridge, the same set-up was used. The rod with the wire was then attached to the lid of the container. Part of the wire at the end of the set-up's cathode side was exposed to the air to measure the voltage and current generated. At the same time, it was being sealed, as shown in Figure 3.

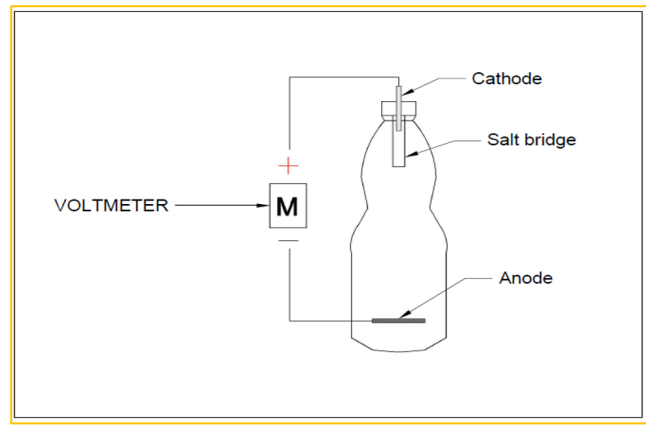

(a)

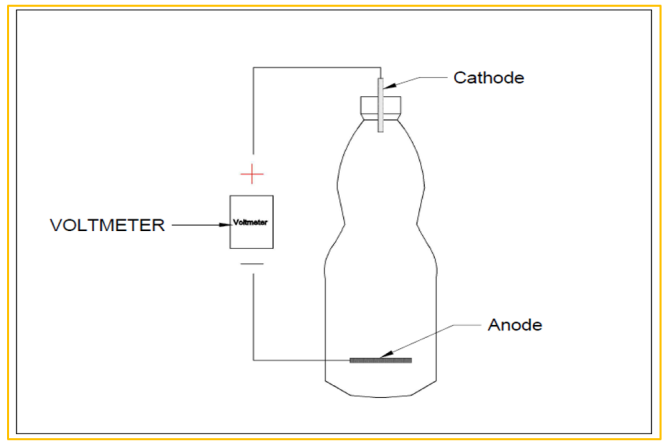

(b)

Figure 2. Presence (a) and Absence (b) of the Salt Bridge

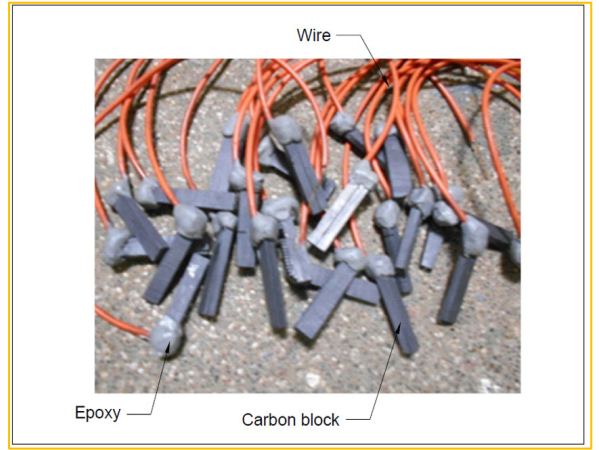

(a)

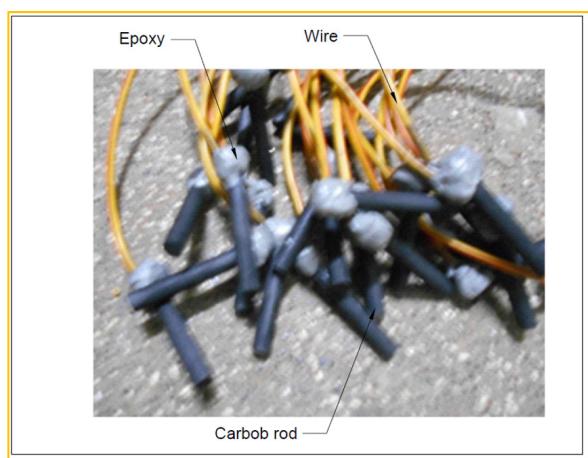

(b)

Figure 3. The Carbon Block (a) and Carbon Rod (b) Electrodes Used in the Experiment

\section{Salt Bridge Preparation}

The salt bridge structure was formed from a transparent polyethylene tube. It was designed at the Department of Pure and Applied Chemistry Laboratory in VSU. Salt bridge content is composed of $50 \mathrm{ml}$ water, $10 \mathrm{~g} \mathrm{KCl}$, and $1 \mathrm{~g}$ agar powder. Each salt bridge contained approximately $10 \mathrm{ml}$. One end of the tube was sealed with plastic cellophane and a cotton at the bottom to prevent the solution from spilling. Solutions were mixed properly and boiled on a hot plate. The medium salt bridge inside the tube was allowed to dry. It was sealed with cotton and covered with aluminum foil at the upper end. Figure 4 shows the different materials used in the preparation of the salt bridge. 


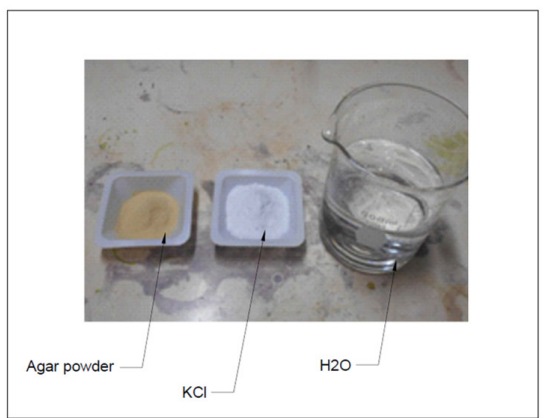

(a)

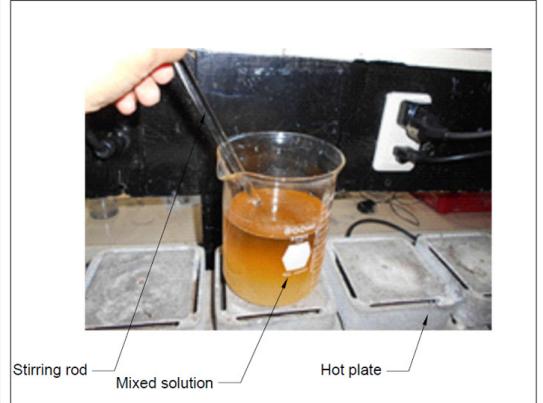

(b)

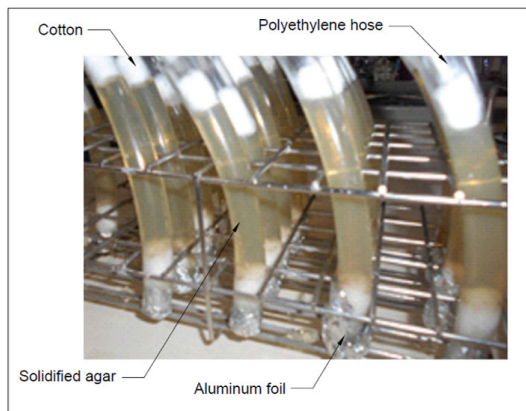

(c)

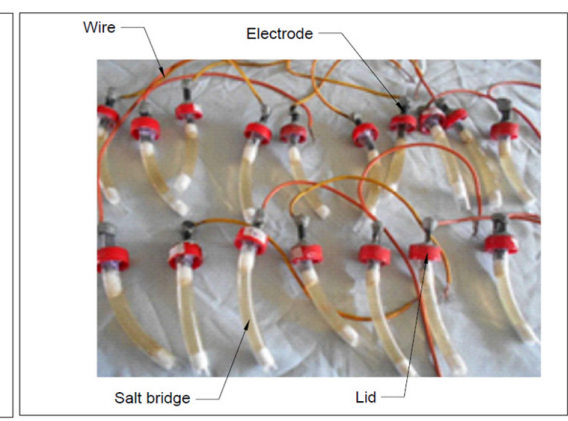

(d)

Figure 4. Materials Used in the Preparation of Salt Bridge

\section{Setting the Chamber of the MFC}

The 1.5 liter-sized soft drink plastic containers were used as chambers of the MFC. Hot water was also used to properly clean the said containers before using them to remove unnecessary substances which may affect the experiment. There were twelve containers used as chambers of the fuel cell and were replicated thrice with a total of thirty-six set-ups (Figure 5). For the anode portion, the carbon electrode was inserted at the bottom part using a kitchen knife. While in the cathode portion, holes were dug at the container's lid using a soldering iron. Half of the electrode was exposed inside the container, and the other half was exposed outside. The salt bridge was attached inside the lower portion of the cathode electrode of the MFC. It was then sealed and fixed using epoxy.

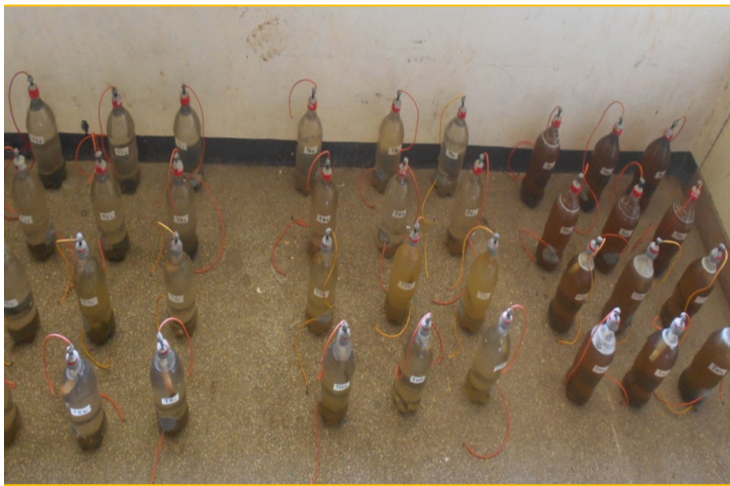

Figure 5. The Improvised Air-cathode MFC Used in the Experiment

\section{Running the Microbial Fuel Cell}

Collected wastewaters from different sources were poured into their respective containers. Containers were sealed immediately with carbon electrodes so that minimal air was captured $(\mathrm{Li}, 2013)$ 
and was locked using epoxy. The numerical multimeter was considered to determine the energy and current readings generated by the improvised MFC (Figure 6).

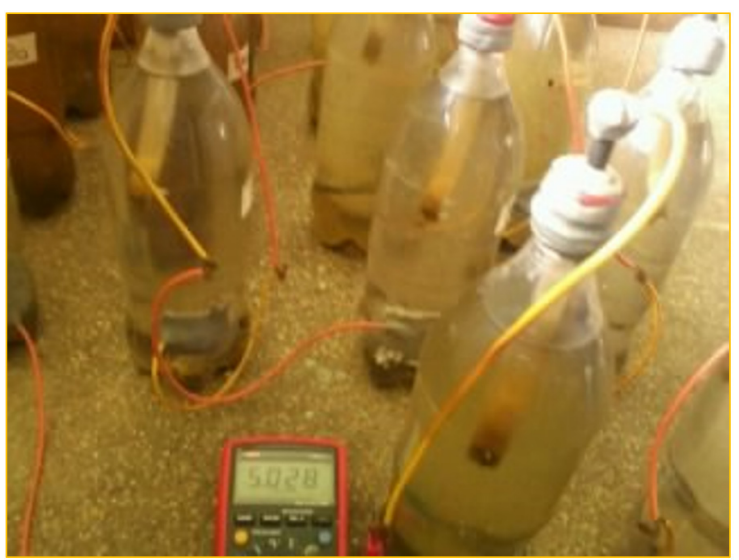

Figure 6. Measuring the Voltage and Current from the MFC

\section{Temperature and $\mathrm{pH}$}

The factors that may affect the study's anaerobic condition, such as temperature and $\mathrm{pH}$, were monitored. Such environmental factors were to account its effect on the fermentation process in the anode chamber. Room temperature (ambient condition) was determined thrice daily at 5:00 AM, 1:00 PM, and 8:00 PM with a glass-type laboratory thermometer. The parallel set-ups were made for the initial and final microbial analysis and the samples' measurements.

\section{Microbial Analysis}

The isolation and characterization of microorganisms present in the three samples were done at the Microbial Analysis Laboratory of the College of Veterinary Medicine in VSU. MFCs were designed and constructed for the easiness of biofilm collection and microbes analysis in the anode electrodes. For preliminary monitoring, a chamber of the microbial fuel cell was used in the isolation of microbes. A Screening and evaluation of microorganisms in wastewaters from the VSU pond, Abaca processing mill, and Ricefield for electricity production was made. The wastewaters from the pond, abaca processing mill and rice field were employed and assessed as substrates by quantifying the electrical energy produced in the fuel cells. Separation and description of microorganisms that contributed and produced energy was done. Hence, the microorganisms were separated from a chamber air-cathode MFC. All separated microorganisms were cleansed and assessed based on their cultural features, this is precisely of their media development behavior, such as nutrient liquid medium. Microbial count and separation at the anode were done before fermentation and on the last day of fermentation process.

\section{Experimental Designs, Data and Statistical Analysis}

A Repeated-Measures ANOVA for $3 \times 2 \times 2$ factorial experimental design was used in three replicates with three levels of variables, namely: different sources of wastewater (pond, abaca pulp mill, and rice field); types of carbon electrodes (dry cell battery and carbon block); and absence/ presence of salt bridge. The three variables were considered to have significant effects on the generated voltage and current of the MFC. Data (voltage; $\mathrm{mV}$ and current; $\mathrm{mA}$ ) were monitored three times a day (5:00 AM, 1:00 PM, and 8:00 $\mathrm{PM})$. The generated voltage and current per day were the average of the three measurements. Comparison between means was achieved using Tukey's HSD test. Table 1 shows the experimental layout. 
Table 1. The data shows the treatment combinations of the experiments for determining the optimum voltage and current generated designated as factors $X_{1}, X_{2}$, and $X_{3}$.

\begin{tabular}{cccc}
\hline \multirow{2}{*}{ Treatment } & \multicolumn{3}{c}{ Significant Variables } \\
\cline { 2 - 4 } & $\mathrm{X}_{1}$ & $\mathrm{X}_{2}$ & $\mathrm{X}_{3}$ \\
\hline $\mathrm{T}_{1}$ & $\mathrm{~A}_{1}$ & $\mathrm{~B}_{1}$ & $\mathrm{C}_{1}$ \\
$\mathrm{~T}_{2}$ & $\mathrm{~A}_{1}$ & $\mathrm{~B}_{2}$ & $\mathrm{C}_{1}$ \\
$\mathrm{~T}_{3}$ & $\mathrm{~A}_{2}$ & $\mathrm{~B}_{1}$ & $\mathrm{C}_{1}$ \\
$\mathrm{~T}_{4}$ & $\mathrm{~A}_{2}$ & $\mathrm{~B}_{2}$ & $\mathrm{C}_{1}$ \\
$\mathrm{~T}_{5}$ & $\mathrm{~A}_{3}$ & $\mathrm{~B}_{1}$ & $\mathrm{C}_{1}$ \\
$\mathrm{~T}_{6}$ & $\mathrm{~A}_{3}$ & $\mathrm{~B}_{2}$ & $\mathrm{C}_{1}$ \\
$\mathrm{~T}_{7}$ & $\mathrm{~A}_{1}$ & $\mathrm{~B}_{1}$ & $\mathrm{C}_{2}$ \\
$\mathrm{~T}_{8}$ & $\mathrm{~A}_{1}$ & $\mathrm{~B}_{2}$ & $\mathrm{C}_{2}$ \\
$\mathrm{~T}_{9}$ & $\mathrm{~A}_{2}$ & $\mathrm{~B}_{1}$ & $\mathrm{C}_{2}$ \\
$\mathrm{~T}_{10}$ & $\mathrm{~A}_{2}$ & $\mathrm{~B}_{2}$ & $\mathrm{C}_{2}$ \\
$\mathrm{~T}_{11}$ & $\mathrm{~A}_{3}$ & $\mathrm{~B}_{1}$ & $\mathrm{C}_{2}$ \\
$\mathrm{~T}_{12}$ & $\mathrm{~A}_{3}$ & $\mathrm{~B}_{2}$ & $\mathrm{C}_{2}$ \\
\hline X1-Sources of & A1-Pond & B1-Carbon & $\mathrm{C}_{1}$-Absence \\
Wastewater & A2-Abaca & Rod & C2-Presence \\
X2-Types & PulpMill & B2-Carbon & \\
ofCarbon & A3-Rice Field & Block & \\
Electrodes & & & \\
X3-Salt Bridge & & & \\
& & &
\end{tabular}

\subsection{Results and Discussion}

Working Mechanisms of the Laboratory AirCathode Microbial Fuel Cell

A single chamber laboratory air-cathode MFC was designed to determine the electrical energy (voltage and current) generated from three different sources of wastewater (pond, abaca processing mill, and rice field) using two types of carbon electrodes (carbon block and carbon rod) with the presence and absence of a salt bridge. The laboratory MFC consisted of four main parts namely: the anode as the negative terminal; the cathode as the positive terminal; salt bridge as the ionic conduction medium; and an electrical load. These parts are shown in Figure 2 and Figure 3. The bacteria must be grown in an anaerobic environment in order to produce electricity. Due to the bacteria's ability to transfer electrons to an insoluble electron acceptor (anode electrode), the electrons through external loads can be used in generating electricity before they go back to the cathode to counter with hydrogen, as well as the oxygen creating water, as revealed by Jardon (2006). In other words, the electrons transfer via wires to the cathode. The potential difference or the voltage between the anode and the cathode and the flow of electrons results in electrical power generation. Hence, the protons flow through the salt bridge going to cathode. These protons must migrate to the counter electrode to combine with electrons and oxygen to form water and close the circuit (Logan, 2005). Figure 7 shows the flow of charges in a laboratory air cathode MFC.

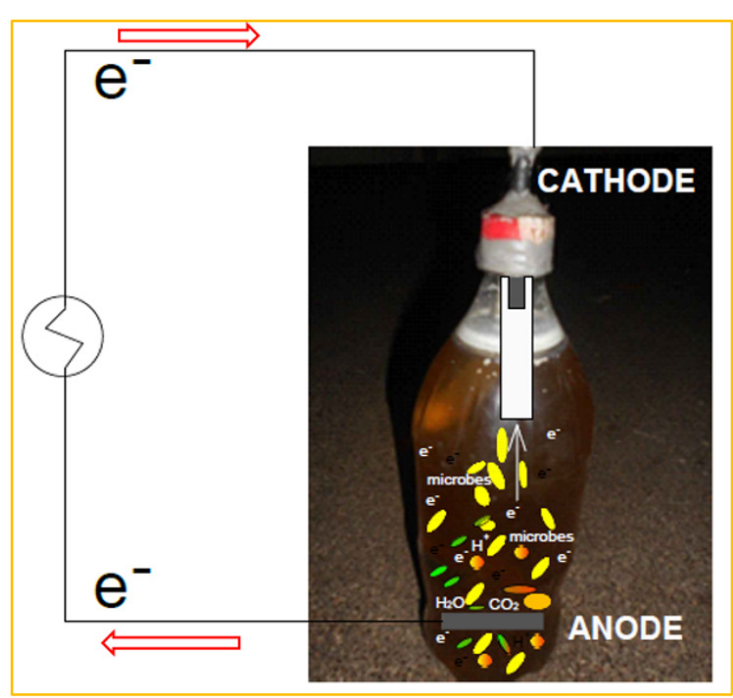

Figure 7. The Flow of Charges in Laboratory Air-cathode MFC

Voltage and Current Generated by the Improvised Air-Cathode MFC

The voltages and currents were covered from the $3 \times 2 \times 2$ factorial experiment. The experiment's MFC set-up was done to determine the effects of different variables on the generated voltage and 
current. The three selected variables used were wastewater sources, type of carbon electrodes, and a salt bridge. The factorial experiment used the three experimental factors $X_{1}, X_{2}$, and $X_{3}$, each with corresponding levels. Levels for the source of wastewater were from a pond, an abaca pulp mill, and rice fields. Likewise, the levels of carbon electrodes, carbon rod, carbon block, and for the salt bridge, were the absence and presence. The combinations of these factors' levels resulted in twelve replicated treatments thrice and resulted in 36 experimental units. Their potential difference (voltage) and current within 20 days were measured. MFC's as affected by the levels of wastewater source, type of carbon electrodes, and the salt bridge is shown in the figure below.

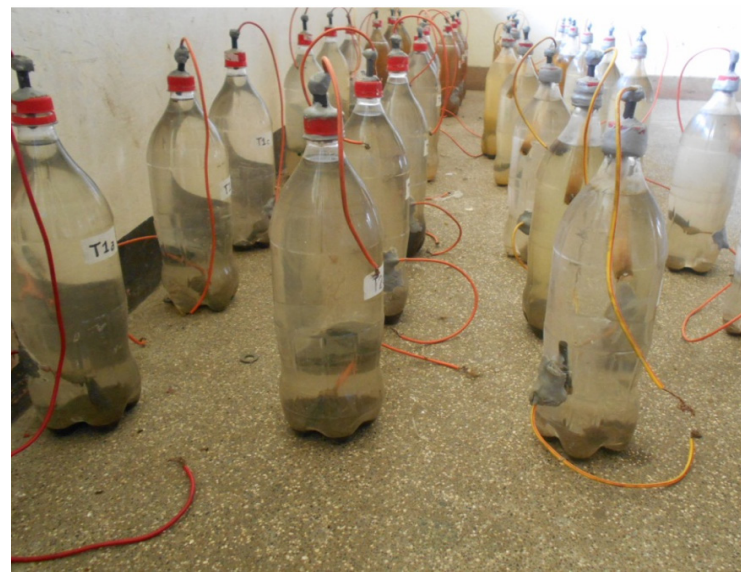

Figure 8. Observation Set-ups Where Voltages and Amperages were Monitored

The mean voltage and current of the different treatments associated with the number of days are shown in Figure 9 and Figure 10. The mean of actual voltage reading reached $716 \mathrm{mV}$ while the current reached $0.34 \mathrm{~mA}$. Within 20 days of measurement, Treatment 9 (wastewater from abaca pulp mill using carbon rod electrodes with the presence of salt bridge) reached a maximum voltage and current levels with the highest mean response value of $578.7 \mathrm{mV}$ and $0.2022 \mathrm{~mA}$, respectively.

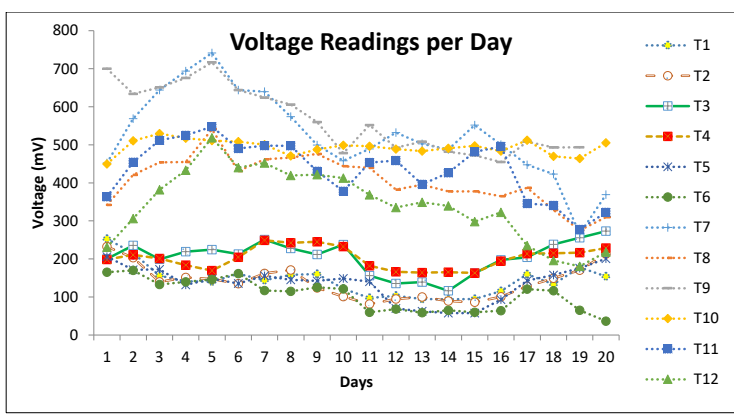

Figure 9. The Plot of the Mean Voltage Value of All Treatments at 20 Days of Measurement

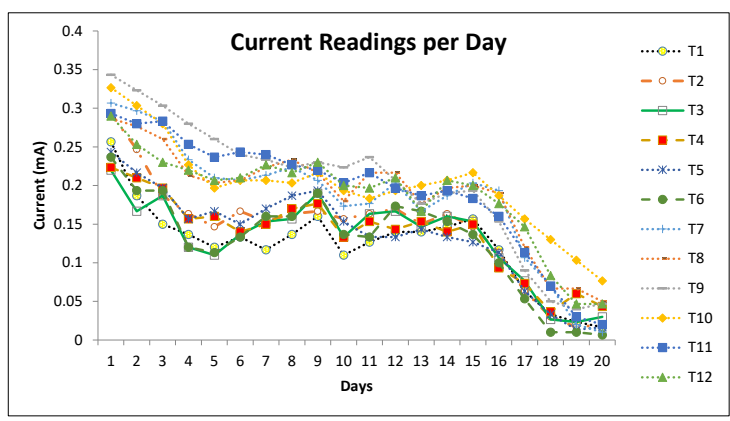

Figure 10. The Plot of the Mean Current Value of All Teatments at 20 Days of Measurement

The statistical analysis of the data for the average voltage and current of three main variables is shown in Table $2 \mathrm{a}$ (voltage) and Table $2 \mathrm{~b}$ (current). The estimates for the analysis of different variables in the $3 \times 2 \times 2$ factorial experiment revealed that the voltage, sources of wastewater, types of carbon electrodes, and the salt bridge had a positive effect. Moreover, these three factors were all significant. The interaction between factors, the sources of wastewater and types of carbon electrodes, and the interaction between the salt bridge and types of electrodes used had positive effects. In contrast, the rest were considered as negative effects. Although the duration of days and treatments were not stated in the objectives, it showed a significant effect on the voltage and current generation. Also, treatment means showed a positive effect. For the current readings, it was found out that only the 
salt bridge had positive effects. On the other hand, those remaining factors and interactions (Table 3 ) were not significant, showing a negative effect on the experiment.

\section{Variables Affecting the Voltage and Current of the MFC}

Among the three different sources, abaca pulp mill wastewater showed the most significant effects in generating electricity for voltage and current, followed by wastewater from pond and rice fields, respectively. Wastewater from the abaca pulp mill showed a significant positive effect with the mean voltage of $365.563 \mathrm{mV}$ and the mean current of $0.168 \mathrm{~mA}$, as shown in Table
$3 a$ and Table $3 b$. One of the possible reasons that wastewater from the abaca pulp mill generated a higher amount of electricity than other sources was the fact that it came from industrial plants. The industrial waste contained high amounts of various organic and inorganic materials and toxic trace elements accumulated in samples in excessive quantities under long-term conditions. This result is in consonant to the existing literature of studies in dealing with the pulp and paper industry's wastewater source (Rossi et al., 2019; Zhang et al., 2019; Gellman,1988; Abedinzadeh et al., 2018). Thus, such factors considerably affected the production of electricity coming from the abaca pulp mill industry.

Table 2. ANOVA Effect of the Three Main Variables to the Voltage (a) and Current (b) in the $3 \times 2 \times 2$ Factorial Experiment of the MFC

(a)

\begin{tabular}{lrrrrr}
\hline Sources of Variation & Sum of Squares & df & Mean Square & $F_{\text {computed }}$ & p-value \\
\hline Intercept & 68413621.500 & 1 & 68413621.500 & $3835.015^{* *}$ & $<0.001$ \\
X1 & 1479251.378 & 2 & 739625.689 & $41.461^{* *}$ & $<0.001$ \\
X2 & 509070.868 & 1 & 509070.868 & $28.537^{* *}$ & $<0.001$ \\
X1 ${ }^{*}$ X2 & 29843.811 & 2 & 14921.906 & $0.836^{\text {ns }}$ & 0.445 \\
X3 & 16863967.330 & 1 & 16863967.330 & $945.332^{* *}$ & $<0.001$ \\
X1 ${ }^{*}$ X3 & 129159.144 & 2 & 64579.572 & $3.620^{*}$ & 0.042 \\
X2 ${ }^{*}$ X3 & 296826.613 & 1 & 296826.613 & $16.639^{* *}$ & $<0.001$ \\
X1 ${ }^{*}$ X2 ${ }^{*} 33$ & 29459.733 & 2 & 14729.867 & $0.826^{\text {ns }}$ & 0.450 \\
\hline
\end{tabular}

(b)

\begin{tabular}{lcrrrr}
\hline Sources of Variation & Sum of Squares & df & Mean Square & $F_{\text {computed }}$ & -value \\
\hline Intercept & 19.231 & 1 & 19.231 & $6925.885^{* *}$ & $<0.001$ \\
X1 & 0.008 & 2 & 0.004 & $1.435^{\text {ns }}$ & 0.258 \\
X2 & 0.002 & 1 & 0.002 & $0.639^{\text {ns }}$ & 0.432 \\
X1 ${ }^{*}$ X2 & 0.011 & 2 & 0.006 & $2.005^{\text {ns }}$ & 0.157 \\
X3 & 0.630 & 1 & 0.630 & $226.723^{* *}$ & $<0.001$ \\
X1 ${ }^{*}$ X3 & 0.006 & 2 & 0.003 & $0.994^{\text {ns }}$ & 0.385 \\
X2 ${ }^{*}$ X3 & 0.002 & 1 & 0.002 & $0.685^{\text {ns }}$ & 0.416 \\
X1 ${ }^{*}$ X2 *3 & 0.003 & 2 & 0.001 & $0.493^{\text {ns }}$ & 0.617 \\
\hline X1-Sources of Wastewater & **-Highly significant at 1\% & & & \\
X2-Types of Carbon Electrodes & $*$ - significant at 5\% & & & \\
X3-Presence of Salt Bridge & ns-Not significant & & &
\end{tabular}


Table 3. Average Voltage (a) and Current (b) of Microbial Fuel Cell Affected by the Three Sources of Wastewater

(a)

\begin{tabular}{|c|c|c|c|c|}
\hline \multirow{2}{*}{$\begin{array}{c}\text { Source of } \\
\text { Wastewater }\end{array}$} & \multirow{2}{*}{ Mean } & \multirow{2}{*}{$\begin{array}{l}\text { Standard } \\
\text { Error }\end{array}$} & \multicolumn{2}{|c|}{$\begin{array}{l}\text { 95\% Confidence } \\
\text { Interval }\end{array}$} \\
\hline & & & $\begin{array}{l}\text { Lower } \\
\text { Bound }\end{array}$ & $\begin{array}{l}\text { Upper } \\
\text { Bound }\end{array}$ \\
\hline Pond & $304.463^{b}$ & 8.621 & 286.669 & 322.256 \\
\hline $\begin{array}{l}\text { Abaca pulp } \\
\text { mill }\end{array}$ & $365.563^{a}$ & 8.621 & 347.769 & 383.356 \\
\hline Rice field & $254.729^{c}$ & 8.621 & 236.935 & 272.523 \\
\hline
\end{tabular}

(b)

\begin{tabular}{|c|c|c|c|c|}
\hline \multirow{2}{*}{$\begin{array}{c}\text { Source of } \\
\text { Wastewater }\end{array}$} & \multirow{2}{*}{ Mean } & \multirow{2}{*}{$\begin{array}{l}\text { Standard } \\
\text { Error }\end{array}$} & \multicolumn{2}{|c|}{$\begin{array}{c}95 \% \text { Confidence } \\
\text { Interval }\end{array}$} \\
\hline & & & $\begin{array}{l}\text { Lower } \\
\text { Bound }\end{array}$ & $\begin{array}{l}\text { Upper } \\
\text { Bound }\end{array}$ \\
\hline Pond & $0.160^{c}$ & 0.003 & 0.153 & 0.168 \\
\hline $\begin{array}{l}\text { Abaca pulp } \\
\text { mill }\end{array}$ & $0.168^{\mathrm{a}}$ & 0.003 & 0.161 & 0.175 \\
\hline Rice field & $0.162^{b}$ & 0.003 & 0.155 & 0.169 \\
\hline
\end{tabular}

Note: Means with the same letter are not significantly different.

One of MFC's critical challenges was selecting proper electrodes (cathode and anode), affecting the power output (Zhang et al., 2019; Cheng et al., 2006). Two types of carbon electrodes were used in this study namely; the carbon rod and the carbon block. The same electrodes were used for both anode and cathode, allowing microbes' growth and taking some electrons. However, the conductivity and biocompatibility of carbon-based materials still have space to improve. For both voltage and current generated by the MFC, carbon rod gave the better performance compared with carbon block, which produced mean voltage and current of $334.842 \mathrm{mV}$ and $0.165 \mathrm{~mA}$ (as shown in Table 4a and Table 4b). One of the reasons why carbon rod was an effective electrode used in this experiment was its very inert carbon bonded in planes with very strong covalent bonds though only in aqueous electrolysis. The results is consistent to the findings of Lyngberg et al. (2001) and Gosse et al. (2007).

Table 4. Average Voltage (a) and Current (b) of MFC Affected by the Two Types of Carbon Electrodes

(a)

\begin{tabular}{|c|c|c|c|c|}
\hline \multirow{2}{*}{$\begin{array}{l}\text { Types of } \\
\text { Carbon } \\
\text { Electrodes }\end{array}$} & \multirow{2}{*}{ Mean } & \multirow{2}{*}{$\begin{array}{l}\text { Std. } \\
\text { Error }\end{array}$} & \multicolumn{2}{|c|}{$\begin{array}{l}\text { 95\% Confidence } \\
\text { Interval }\end{array}$} \\
\hline & & & $\begin{array}{l}\text { Lower } \\
\text { Bound }\end{array}$ & $\begin{array}{l}\text { Upper } \\
\text { Bound }\end{array}$ \\
\hline Carbon rod & $334.842^{\mathrm{a}}$ & 7.039 & 320.313 & 349.370 \\
\hline $\begin{array}{l}\text { Carbon } \\
\text { block }\end{array}$ & $281.661^{b}$ & 7.039 & 267.132 & 296.190 \\
\hline
\end{tabular}

(b)

\begin{tabular}{lcccc}
\hline \multirow{2}{*}{$\begin{array}{c}\text { Types of } \\
\text { Carbon }\end{array}$} & Mean & $\begin{array}{c}\text { Std. } \\
\text { Electrodes }\end{array}$ & & \multicolumn{2}{c}{$\begin{array}{c}\text { 95\% Confidence } \\
\text { Interval }\end{array}$} \\
\cline { 4 - 5 } & & $\begin{array}{c}\text { Lower } \\
\text { Bound }\end{array}$ & $\begin{array}{c}\text { Upper } \\
\text { Bound }\end{array}$ \\
\hline Carbon rod & $0.165^{\mathrm{a}}$ & 0.003 & 0.159 & 0.171 \\
$\begin{array}{l}\text { Carbon } \\
\text { block }\end{array}$ & $0.162^{\mathrm{b}}$ & 0.003 & 0.156 & 0.168 \\
\hline
\end{tabular}

Means with the same letter are not significantly different.

Atanacio et al. (2010) reported that a dualchamber MFC separated by the salt bridge using cassava extracts, one of the treatments $(67 \%$ cassava extract concentration; $5 \%$ salt ratio in the salt bridge) in the $3 \times 3$ factorial experiment reached the maximum voltage ( $435 \mathrm{mV}$ to $546 \mathrm{mV}$ ) with an average voltage of 371 to $409 \mathrm{mV}$. Also, Tan et al. (2013) revealed that a single chamber MFC affected by the presence and absence of membrane from cassava wastewater could generate an average voltage of $720.83 \mathrm{mV}$ (present) and $241.50 \mathrm{mV}$ (absent) with a corresponding average current of $0.50 \mathrm{~mA}$ (present) and $0.13 \mathrm{~mA}$ (absent), respectively. In this study, two designs were used in single chamber air cathode MFC with the salt bridge's absence and presence. It was found out that these two designs greatly influenced the voltage and current generated by the MFC. Using an MFC with a salt bridge, it was possible 
to produce $461.294 \mathrm{mV}$ and $0.193 \mathrm{~mA}$. With the absence of a salt bridge, MFC could generate a lesser voltage of $155.208 \mathrm{mV}$ and a current of 0.134 $\mathrm{mA}$ compared to the other (Table $5 \mathrm{a}$ and Table 5b). Thus, the salt bridge significantly contributed to the generation of current, which sustained each electron that produced and separated the anode and cathode physically at the same time (J. Liu et al., 2019; X.Liu et al., 2018). It allowed the protons to pass and reach the cathode portion. Since half of the cathode was exposed to the air, there is no need for the oxygen to be transferred from the cathode to the anode. The oxygen in the air was already available.

Table 5. Average Voltage (a) and Current (b) of MFC Affected by the Absence and Presence of Salt Bridge

(a)

\begin{tabular}{|c|c|c|c|c|}
\hline \multirow{2}{*}{$\begin{array}{l}\text { Salt } \\
\text { Bridge }\end{array}$} & \multirow{2}{*}{ Mean } & \multirow{2}{*}{$\begin{array}{l}\text { Std. } \\
\text { Error }\end{array}$} & \multicolumn{2}{|c|}{$\begin{array}{l}\text { 95\% Confidence } \\
\text { Interval }\end{array}$} \\
\hline & & & $\begin{array}{l}\text { Lower } \\
\text { Bound }\end{array}$ & $\begin{array}{l}\text { Upper } \\
\text { Bound }\end{array}$ \\
\hline Absence & $155.208^{b}$ & 7.039 & 140.680 & 169.737 \\
\hline Presence & $461.294^{a}$ & 7.039 & 446.766 & 475.823 \\
\hline
\end{tabular}

(b)

\begin{tabular}{ccccc}
\hline \multirow{2}{*}{$\begin{array}{c}\text { Salt } \\
\text { Bridge }\end{array}$} & Mean & $\begin{array}{c}\text { Std. } \\
\text { Error }\end{array}$ & & \multicolumn{2}{c}{$\begin{array}{c}\text { 95\% Confidence } \\
\text { Interval }\end{array}$} \\
\cline { 4 - 5 } & & & $\begin{array}{c}\text { Lower } \\
\text { Bound }\end{array}$ & $\begin{array}{c}\text { Upper } \\
\text { Bound }\end{array}$ \\
\hline Absence & $0.134^{\mathrm{b}}$ & 0.003 & 0.128 & 0.140 \\
Presence & $0.193^{\mathrm{a}}$ & 0.003 & 0.187 & 0.199 \\
\hline
\end{tabular}

Means with the same letter are not significantly different.

\section{Microbial Analysis}

The microbial community is greatly affected and influenced by the substrates used (X. Liu et al., 2018). The voltage and current readings from MFC with single chamber air cathode using plastic containers from the pond, abaca pulp mill, and rice field were determined and compared, as shown in Figure $11 \mathrm{a}$ and Figure $11 \mathrm{~b}$. For the voltage, wastewater from the abaca pulp mill showed higher voltage than pond and rice fields. On the other hand, almost the same trends were observed to produce current among three sources during the entire fermentation process.

Microorganisms were characterized based on their cultural characteristics. Throughout the 20day fermentation process, the total count of 8.94 $\times 10^{5}$ colony forming units (CFU) per $\mathrm{mL}$ was found and purified from the biofilm anodes from pond wastewater. Likewise, $9.14 \times 10^{5} \mathrm{CFU}$ isolates from the abaca pulp mill and $1.65 \times 10^{6} \mathrm{CFU}$ isolates from the rice field were also found. Table 6 shows the total count of isolates characterized based on their type as aerobes, facultative aerobes/anaerobes, and strictly anaerobes. The numbers of isolates were higher during the initial sampling compared to the final sampling. Thus, bacteria in the anodes cannot reproduce since microorganisms died throughout the time of fermentation. It was found out that the rice field's wastewater shows the highest plate count isolates but revealed the lowest voltage and current generated throughout the fermentation process. Maybe, microorganisms present in that source were not that capable as potential electron donors.

Decrease in microbial computations during initial and final sampling resulted in a decrease in voltage and current readings. Since the study was only limited to initial and final microbial analysis, there is a need to consider the monitoring time interval of the microorganisms in the anode whether it could affect the generation of electricity throughout the fermentation process (Kato Marcus et al., 2007; Tan et al., 2013). 


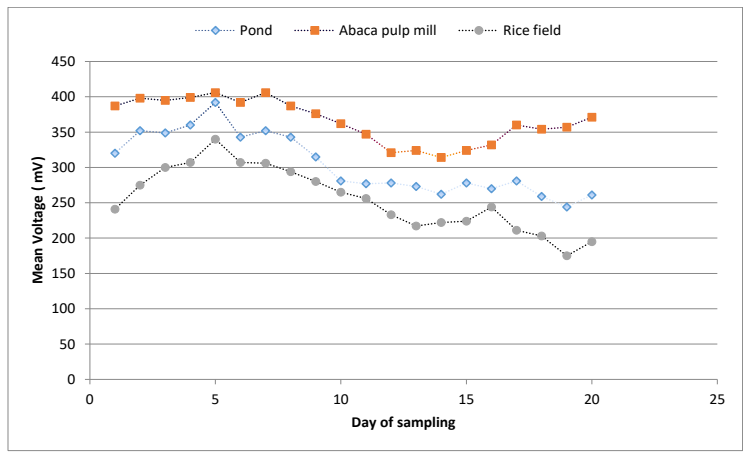

(a)

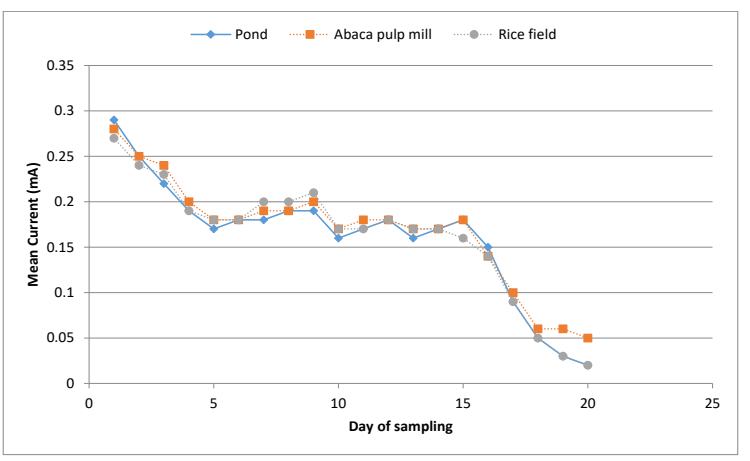

(b)

Figure 11. Mean voltage (a) and current (b) readings of MFC with wastewaters from the pond, abaca pulp mill, and rice field

Table 6. Cultural Characteristics of Potential MFC Isolates Found in Pond Wastewater

\begin{tabular}{|c|c|c|c|c|c|c|c|c|}
\hline \multirow{3}{*}{ 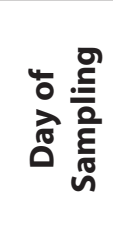 } & \multirow{3}{*}{ 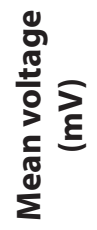 } & \multirow{3}{*}{ 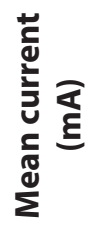 } & \multirow{3}{*}{$\begin{array}{l}\text { Type of } \\
\text { Isolates }\end{array}$} & \multirow{3}{*}{$\begin{array}{l}\text { Total } \\
\text { Plate } \\
\text { Count }\end{array}$} & \multicolumn{4}{|c|}{ CULTURAL CHARACTERISTICS } \\
\hline & & & & & \multicolumn{2}{|c|}{ Nutrient Agar Slant } & \multicolumn{2}{|c|}{ Nutrient Broth } \\
\hline & & & & & Color & Form & Surface & Subsurface \\
\hline & & & Aerobic & $7.1 \times 10^{5}$ & $\begin{array}{l}\text { White, } \\
\text { Yellow, } \\
\text { Red }\end{array}$ & $\begin{array}{l}\text { Echinulate } \\
\text { Filiform }\end{array}$ & Ring & $\begin{array}{l}\text { Turbid, } \\
\text { Cloudy }\end{array}$ \\
\hline \multirow[t]{3}{*}{ Initial } & 320 & 0.29 & $\begin{array}{l}\text { Facultative } \\
\text { Aerobic/ } \\
\text { Anaerobic }\end{array}$ & $1.14 \times 10^{5}$ & $\begin{array}{l}\text { White, } \\
\text { Yellow }\end{array}$ & $\begin{array}{l}\text { Echinulate } \\
\text { Filiform }\end{array}$ & Ring & Turbid \\
\hline & & & $\begin{array}{l}\text { Strictly } \\
\text { Anaerobic }\end{array}$ & $5.5 \times 10^{4}$ & $\begin{array}{l}\text { White, } \\
\text { Yellow }\end{array}$ & $\begin{array}{l}\text { Echinulate } \\
\text { Filiform }\end{array}$ & Ring & $\begin{array}{l}\text { Heavy } \\
\text { turbid }\end{array}$ \\
\hline & & & Aerobic & $6.8 \times 10^{3}$ & $\begin{array}{l}\text { White, } \\
\text { Yellow, } \\
\text { Red }\end{array}$ & $\begin{array}{l}\text { Echinulate } \\
\text { Filiform }\end{array}$ & Ring & $\begin{array}{l}\text { Turbid, } \\
\text { Cloudy }\end{array}$ \\
\hline \multirow[t]{2}{*}{ Final } & 261 & 0.09 & $\begin{array}{l}\text { Facultative } \\
\text { Aerobic/ } \\
\text { Anaerobic }\end{array}$ & $7.3 \times 10^{3}$ & $\begin{array}{l}\text { White, } \\
\text { Yellow, } \\
\text { Orange }\end{array}$ & $\begin{array}{l}\text { Echinulate } \\
\text { Filiform }\end{array}$ & Ring & Turbid \\
\hline & & & $\begin{array}{l}\text { Strictly } \\
\text { Anaerobic }\end{array}$ & $4.0 \times 10^{2}$ & $\begin{array}{l}\text { White, } \\
\text { Orange, } \\
\text { Red }\end{array}$ & $\begin{array}{l}\text { Echinulate } \\
\text { Filiform }\end{array}$ & $\begin{array}{l}\text { Ring, } \\
\text { Membra- } \\
\text { nous }\end{array}$ & $\begin{array}{l}\text { Heavy } \\
\text { turbid }\end{array}$ \\
\hline
\end{tabular}


Table 7. Cultural Characteristics of Potential MFC Isolates Found in Abaca Pulp Mill Wastewater

\begin{tabular}{|c|c|c|c|c|c|c|c|c|}
\hline \multirow{3}{*}{ 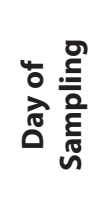 } & \multirow{3}{*}{ 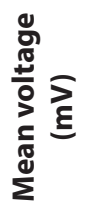 } & \multirow{3}{*}{ 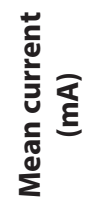 } & \multirow{3}{*}{$\begin{array}{l}\text { Type of } \\
\text { Isolates }\end{array}$} & \multirow{3}{*}{$\begin{array}{l}\text { Total Plate } \\
\text { Count }\end{array}$} & \multicolumn{4}{|c|}{ CULTURAL CHARACTERISTICS } \\
\hline & & & & & \multicolumn{2}{|c|}{ Nutrient Agar Slant } & \multicolumn{2}{|c|}{ Nutrient Broth } \\
\hline & & & & & Color & Form & Surface & Subsurface \\
\hline \multirow{4}{*}{ Initial } & & & Aerobic & $1.33 \times 10^{5}$ & $\begin{array}{l}\text { White, } \\
\text { Light } \\
\text { yellow }\end{array}$ & $\begin{array}{l}\text { Echinulate } \\
\text { Filiform }\end{array}$ & Ring & Turbid \\
\hline & 387 & 0.28 & $\begin{array}{l}\text { Facultative } \\
\text { Aerobic/ } \\
\text { Anaerobic }\end{array}$ & $7.7 \times 10^{5}$ & $\begin{array}{l}\text { White, } \\
\text { Yellow, } \\
\text { Red }\end{array}$ & $\begin{array}{l}\text { Echinulate } \\
\text { Filiform }\end{array}$ & Ring & Slighty turbid \\
\hline & & & $\begin{array}{l}\text { Strictly } \\
\text { Anaerobic }\end{array}$ & $4.0 \times 10^{3}$ & $\begin{array}{l}\text { White, } \\
\text { Yellow, } \\
\text { Red }\end{array}$ & $\begin{array}{l}\text { Echinulate } \\
\text { Filiform }\end{array}$ & Membranous & Heavy turbid \\
\hline & & & Aerobic & $3.1 \times 10^{3}$ & White, Red & $\begin{array}{l}\text { Echinulate } \\
\text { Filiform }\end{array}$ & Ring & Turbid, Cloudy \\
\hline \multirow[t]{2}{*}{ Final } & 371 & 0.05 & $\begin{array}{l}\text { Facultative } \\
\text { Aerobic/ } \\
\text { Anaerobic }\end{array}$ & $3.8 \times 10^{3}$ & $\begin{array}{l}\text { White, } \\
\text { Yellow, } \\
\text { Red }\end{array}$ & $\begin{array}{l}\text { Echinulate } \\
\text { Filiform }\end{array}$ & Ring & Turbid \\
\hline & & & $\begin{array}{l}\text { Strictly } \\
\text { Anaerobic }\end{array}$ & $4.0 \times 10^{2}$ & $\begin{array}{l}\text { White, } \\
\text { Light }\end{array}$ & $\begin{array}{l}\text { Echinulate } \\
\text { Filiform }\end{array}$ & $\begin{array}{l}\text { Ring, } \\
\text { Membranous }\end{array}$ & Heavy turbid \\
\hline
\end{tabular}

Table 8. Cultural Characteristics of Potential MFC Isolates Found in Rice Field Wastewater

\begin{tabular}{|c|c|c|c|c|c|c|c|c|}
\hline \multirow{3}{*}{ 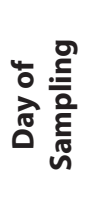 } & \multirow{3}{*}{ 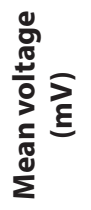 } & \multirow{3}{*}{ 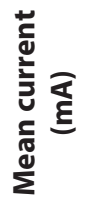 } & \multirow{3}{*}{$\begin{array}{l}\text { Type of } \\
\text { Isolates }\end{array}$} & \multirow{3}{*}{$\begin{array}{l}\text { Total } \\
\text { Plate } \\
\text { Count }\end{array}$} & \multicolumn{4}{|c|}{ CULTURAL CHARACTERISTICS } \\
\hline & & & & & \multicolumn{2}{|c|}{ Nutrient Agar Slant } & \multicolumn{2}{|c|}{ Nutrient Broth } \\
\hline & & & & & Color & Form & Surface & Subsurface \\
\hline \multirow[b]{2}{*}{ Initial } & \multirow[b]{2}{*}{241} & \multirow[b]{2}{*}{0.27} & Aerobic & $5.7 \times 10^{5}$ & $\begin{array}{l}\text { White, } \\
\text { Light yellow }\end{array}$ & $\begin{array}{l}\text { Echinulate } \\
\text { Filiform }\end{array}$ & Ring & Turbid \\
\hline & & & $\begin{array}{l}\text { Facultative } \\
\text { Aerobic/ } \\
\text { Anaerobic }\end{array}$ & $9.8 \times 10^{5}$ & $\begin{array}{l}\text { White, } \\
\text { Yellow }\end{array}$ & $\begin{array}{l}\text { Echinulate } \\
\text { Filiform }\end{array}$ & Ring & $\begin{array}{l}\text { Slightly } \\
\text { turbid }\end{array}$ \\
\hline \multirow{4}{*}{ Final } & \multirow{4}{*}{195} & \multirow{4}{*}{0.02} & $\begin{array}{l}\text { Strictly } \\
\text { Anaerobic }\end{array}$ & $6.6 \times 10^{4}$ & White & $\begin{array}{l}\text { Echinulate } \\
\text { Filiform }\end{array}$ & $\begin{array}{l}\text { Membra- } \\
\text { nous }\end{array}$ & Heavy turbid \\
\hline & & & Aerobic & $3.6 \times 10^{3}$ & $\begin{array}{l}\text { White, } \\
\text { Light yellow, } \\
\text { Red }\end{array}$ & $\begin{array}{l}\text { Echinulate } \\
\text { Filiform }\end{array}$ & Ring & $\begin{array}{l}\text { Turbid, } \\
\text { Cloudy }\end{array}$ \\
\hline & & & $\begin{array}{l}\text { Facultative } \\
\text { Aerobic/ } \\
\text { Anaerobic }\end{array}$ & $3.3 \times 10^{4}$ & $\begin{array}{l}\text { White, } \\
\text { Yellow, } \\
\text { Red }\end{array}$ & $\begin{array}{l}\text { Echinulate } \\
\text { Filiform }\end{array}$ & $\begin{array}{l}\text { Ring, } \\
\text { Membran- } \\
\text { ous }\end{array}$ & Turbid \\
\hline & & & $\begin{array}{l}\text { Strictly } \\
\text { Anaerobic }\end{array}$ & $2.6 \times 10^{2}$ & $\begin{array}{l}\text { White, } \\
\text { Light Yellow, } \\
\text { Orange, Red }\end{array}$ & $\begin{array}{l}\text { Echinulate } \\
\text { Filiform }\end{array}$ & $\begin{array}{l}\text { Ring, } \\
\text { Membran- } \\
\text { ous }\end{array}$ & Heavy turbid \\
\hline
\end{tabular}




\section{Temperature and $\mathrm{pH}$}

Throughout the factorial experiment, the room temperature and the $\mathrm{pH}$ were recorded. The temperature was recorded a day thrice at 5:00 a.m., 1:00 p.m., and 9:00 p.m. It was found out that temperature at room condition ranged from 23 to $3^{\circ} \mathrm{C}$. For the $\mathrm{pH}$ reading, it was only monitored thrice throughout the 20 days of the fermentation process. It was found out that the reading ranged from 6.8-7.2.

\section{Test for the Presence of Electricity}

The presence of electricity produced was tested by connecting an alligator clip connector through the wires attached at each chamber being connected in series and fitted to a calculator to operate it. Figure 12 shows the tests for the power present.

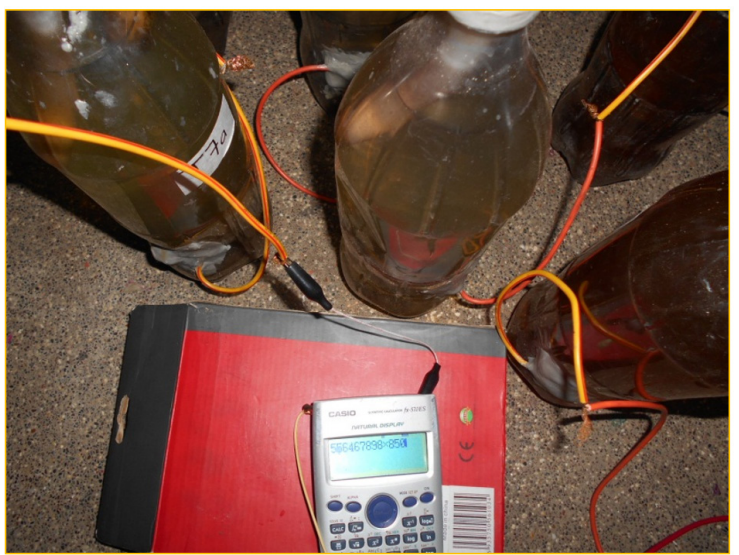

Figure 12. Test for the presence of electricity

\section{0 Conclusion}

It is concluded that electrical energy could be produced from MFCs' nurtured with wastewater from different sources using two types of carbon electrodes employing the absence and salt bridge presence. Wastewater from the pond generated a mean voltage and current of $304.463 \mathrm{mV}$ and $0.162 \mathrm{~mA}$. Likewise, the abaca pulp mill generated $365.563 \mathrm{mV}$ and $0.168 \mathrm{~mA}$. At the same time, wastewater from the rice field generated 254.729 $\mathrm{mV}$ and $0.160 \mathrm{~mA}$, respectively. MFC using abaca pulp mill wastewater as substrate, carbon rod as anode and cathode electrodes, and provided with salt bridge gives the maximum electrical power generation of $578.7 \mathrm{mV}$ and $0.2022 \mathrm{~mA}$. Aerobic, facultative aerobic/anaerobic and strictly anaerobic which were contributed to the power generation in MFC were contained in the pond, abaca pulp mill, and rice field wastewater; actual count ranges from $10^{5}$ to $10^{6} \mathrm{CFU}$ per $\mathrm{mL}$. Throughout the 20-day fermentation process, a maximum count of 1.65 $\times 10^{6} \mathrm{CFU}$ per $\mathrm{mL}$ was found in three sources. For future research, it is recommended that one may consider other wasterwater such as blackwater and greywater that also provides a potential source of electrical energy.

\section{References}

Abedinzadeh, N., Shariat, M., Monavari, S. M., \& Pendashteh, A. (2018). Evaluation of color and COD removal by Fenton from biologically (SBR) pre-treated pulp and paper wastewater. Process Safety and Environmental Protection, 116, 82-91. https:// doi.org/10.1016/j.psep.2018.01.015

Ashoka, H., Shalini, R., \& Bhat, P. (2012). Comparative studies on electrodes for the construction of microbial fuel cell. International Journal of Advanced Biotechnology and Research,3(4), 785-789. https://www.researchgate.net/ publication/325486176_COMPARATIVE_ STUDIES_ON_ELECTRODES_FOR_THE_ CONSTRUCTION_OF_MICROBIAL_FUEL_CELL 
Atanacio, M. A. R., Tan, D. L. S., \& Amestoso, F. J. (2010). Cassava grates processing wastes as source of electrical energy. Annals of Tropical Research, 32(1), 55-71. https://doi. org/10.32945/atr3214.2010

Banaticla, J. E. G., \& Rivera, W. L. (2011). Detection and subtype identification of Blastocystis isolates from wastewater samples in the Philippines. Journal of Water and Health, 9(1), 128-137. 10.2166/wh.2010.127

Brockway, P. E., Owen, A., Brand-Correa, L. I., \& Hardt, L. (2019). Estimation of global finalstage energy-return-on-investment for fossil fuels with comparison to renewable energy sources. Nature Energy, 4, 612-621. https://doi. org/10.1038/s41560-019-0425-z

Cheng, S., Liu, H., \& Logan, B. E. (2006). Increased performance of single-chamber microbial fuel cells using an improved cathode structure. Electrochemistry Communications, 8(3), 489-494. https://doi.org/10.1016/j. elecom.2006.01.010

Gellman, I. (1988). Environmental effects of paper industry wastewaters-an overview. Water Science and Technology, 20(2), 59-65. https:// doi.org/10.2166/wst.1988.0046

Gosse, J. L., Engel, B. J., Rey, F. E., Harwood, C. S., Scriven, L. E., \& Flickinger, M.C. (2007). Hydrogen production by photoreactivenanoporous latex coatings of nongrowing Rhodopseudomonaspalustris CGA009. Biotechnology Progress, 23(1), 124130. $10.1021 / \mathrm{bp060254+}$

Jardon, M. (2006, May 10). Microbial fuel cells from Rhodopherax ferrireducens. The Science
Creative Quarterly. https://www.scq.ubc. $\mathrm{ca} /$ microbial-fuel-cells-from-rhodopheraxferrireducens/

Jensen, O., \& Wu, H. (2018). Urban water security indicators: Development and pilot. Environmental Science \& Policy, 83, 33-45. https://doi.org/10.1016/j.envsci.2018.02.003

Kato Marcus, A., Torres, C. I., \&Rittmann, B. E. (2007). Conduction based modeling of the biofilm anode of a microbial fuel cell. Biotechnology and Bioengineering, 98(6), 1171-1182. 10.1002/bit.21533

Kharbanda, P., Madaan, T., Sharma, I., Vashishtha, S., Kumar, P., Chauhan, A., Mittal, S., Bangruwa, J. S., \&Verma, V. (2019). Ferrites: Magnetic materials as an alternate source of green electrical energy. Heliyon, 5, e01151. 10.1016/j.heliyon.2019.e01151

Kim, J. R., Jung, S. H., Regan, J. M., \& Logan, B. E. (2007). Electricity generation and microbial community analysis of alcohol powered microbial fuel cells. Bioresource Technology, 98(13), 2568-2577. https://doi.org/10.1016/j. biortech.2006.09.036

Li, J. (2013). An experimental study of microbial fuel cells for electricity-generating: Performance characterization and capacity improvement. Journal of Sustainable Bioenergy Systems, 3(3), 171-178. 10.4236/jsbs.2013.33024

Liu, J., Chen, X., Cao, S., \& Yang, H. (2019). Overview on hybrid solar photovoltaic-electrical energy storage technologies for power supply to buildings. Energy Conversion and Management, 187, 103-121. https://doi. org/10.1016/j.enconman.2019.02.080 
Liu, X., Shi, L., \&Gu, J. D. (2018). Microbial electrocatalysis: Redox mediators responsible for extracellular electron transfer.Biotechnology Advances, 36(7), 1815-1827. https://doi. org/10.1016/j.biotechadv.2018.07.001

Logan, B. E. (2005). Simultaneous wastewater treatment and biological electricity generation. Water Science and Technology, 52(1-2), 31-37. 10.2166/wst.2005.0495

Lyngberg, O. K., Ng, C. P., Thiagarajan, V., Scriven, L. E., \&Flickinger, M. C. (2001). Eng in e ering the microstructure and permeability of thin multilayer latex biocatalytic c o a $\mathrm{t}$ i $\mathrm{n} \mathrm{g} \mathrm{s}$ containing E. coli. Biotechnology Progress, 17(6), 1169-1179. https://doi.org/10.1021/ bp0100979

Liu, X., Shi, L., \&Gu, J. D. (2018). Microbial electrocatalysis: Redox mediators responsible forextracellularelectrontransfer. Biotechnology Advances, 36(7), 1815-1827. https://doi. org/10.1016/j.biotechadv.2018.07.001

Min, B., Kim, J.R., Oh, S.E., Regan, J. M., \& Logan, B. E. (2005). Electricity generation from swine wastewater using microbial fuel cells. Water Research, 39(20), 4961-4968. https://doi. org/10.1016/j.watres.2005.09.039

Panwar, N. L., Kaushik, S. C., \& Kothari, S. (2011). Role of renewable energy sources in environmental protection: A review. Renewable and Sustainable Energy Reviews, 15(3), 1513-1524. https://doi.org/10.1016/j. rser.2010.11.037

Rossi, R., Cario, B. P., Santoro, C., Yang, W., Saikaly, P. E., \& Logan, B. E. (2019). Evaluation of electrode and solution area-based resistances enables quantitative comparisons of factors impacting microbial fuel cell performance. Environmental Science \& Technology, 53(7), 3977-3986. 10.1021/acs.est.8b06004

Ryu, H., \& Kim, S. W. (2019). Emerging pyroelectric nanogenerators to convert thermal energy into electrical energy. Small. https://doi. org/10.1002/smll.201903469

Tan, D. L. S., Tan, J. D., Atanacio, M.A.R., \& Delantar, R. (2013). Potential of rootcrops as source of electrical energy. Annals of Tropical Research, 35(2), 22-39. 10.32945/atr3522.2013

Treesubsuntorn, C., Chaiworn, W., Surareungchai, W., \& Thiravetyan, P. (2019). Increasing of electricity production from Echinodosuscordifolius- microbial fuel cell by inoculating Bacillus thuringiensis. Science of the Total Environment, 686, 538-545. https:// doi.org/10.1016/j.scitotenv.2019.06.063

Zhang, Y., Liu, M., Zhou, M., Yang, H., Liang, L., \&Gu, T. (2019). Microbial fuel cell hybrid systems for wastewater treatment and bioenergy production: Synergistic effects, mechanisms and challenges. Renewable and Sustainable Energy Reviews, 103, 13-29. https://doi. org/10.1016/j.rser.2018.12.027

Zielke, E. A. (2005). Design of a single chamber microbial fuel cell. http://www.lacc-terryb. com/files/Engr_499_final_zielke.pdf 